\title{
OD PRZESTĘPSTWA BLUŹNIERSTWA DO PRAWNOKARNEJ OCHRONY PRZEKONAŃ RELIGIJNYCH WE FRANCUSKIM PRAWIE KARNYM
}

\section{Wstęp}

Słowo „bluźnierstwo” określa zachowanie, które ma na celu obrazę Boga, odebranie Mu czci lub wyrażenie złości przeciwko Niemu. W węższym znaczeniu bluźnierstwo oznacza „urąganie, lżenie, szydzenie skierowane przeciwko Bogu albo stworzeniom lub rzeczom - ze względu na Boga, wyrażające się w myśli, słowie lub czynie"1. W szerszym ujęciu, wykraczającym poza zakres religijny, za bluźnierstwo uważa się takie zachowania, które „uwłaczają temu, co jest przez kogoś uważane za godne szacunku, co jest ogólnie poważane, cenione, zwłaszcza urągać temu co jest przez religię uważane za święte" ${ }^{2}$. Geneza tego przestępstwa sięga czasów starożytnych. W XVIII-wiecznej Europie pod wpływem filozofii oświecenia zmienił się charakter prawny bluźnierstwa. Bóg przestał być przedmiotem ochrony prawnej tego przestępstwa. W przepisach XIX-wiecznych kodeksów karnych karalności podlegały obraza czci religijnej wspólnoty albo obraza religijna ludzi wierzących, co było związane $\mathrm{z}$ odejściem od teologicznego pojmowania bluźnierstwa ${ }^{3}$.

* Dr, Katedra Prawa Wyznaniowego, Wydział Prawa, Prawa Kanonicznego i Administracji, Katolicki Uniwersytet Lubelski Jana Pawła II, e-mail: michal.zawislak@kul.pl; https/orcid.org/0000-0002-0824-5489.

1 L. Stachowiak, Bluźnierstwo, w: Encyklopedia Katolicka, t. 2, red. F. Gryglewicz, R. Łukaszczyk, Z. Sułowski, Lublin 1976, kol. 669.

2 Tamże.

3 W. Wasil, Od bluźnierstwa do przestępstwa, czyli co tak naprawdę chroni państwo: Boga czy uczucia religijne? Studium historyczno-prawne, Kościół i Prawo 8(21)2019, nr 1, s. 204-207. 
Celem niniejszego artykułu jest przeanalizowanie procesu polegającego na przejściu od obowiązywania przestępstwa bluźnierstwa do objęcia prawnokarną ochroną przekonań religijnych, ze zwróceniem uwagi na podstawowe determinanty tego procesu i z uwzględnieniem specyfiki lokalnego prawa Alzacji-Mozeli. Natomiast podstawowym problemem badawczym będzie odpowiedź na pytanie o konsekwencje, jakie wskazana zmiana spowodowała w zakresie - najogólniej rzecz ujmując - prawnokarnej ochrony osób wierzących i ich uczuć religijnych. Analizie zostaną poddane przepisy prawa karnego obowiązujące na terytorium Francji, z wyłączeniem terytoriów zamorskich. Szczególna uwaga zostanie skierowana na przepisy lokalnego prawa karnego Alzacji-Mozeli, które pomimo swojej odrębności stanowią część systemu prawa francuskiego.

\section{Przestępstwo bluźnierstwa przeciwko Bogu}

Bluźnierstwo jako przestępstwo przeciwko Bogu funkcjonowało w prawie od czasów starożytności. Wpływ chrześcijaństwa sprawił, że bluźnierstwo stało się przestępstwem państwowym. Bardzo restrykcyjne kary za obrazę Boga były charakterystyczne dla regulacji prawnych okresu średniowiecza ${ }^{4}$.

W XV i XVI w. odnotowano wzrost procesów za bluźnierstwo. Z kolei XVII w. określany jest jako okres swoistego polowania na bluźnierców. Według akt francuskiego trybunału Parlament de Paris w latach 1700-1790 skazano za przestępstwo bluźnierstwa 91 osób. Ostatnią osobą ukaraną za bluźnierstwo we Francji był Jean-François de la Barre, co miało miejsce w $1766 \mathrm{r}^{5}$

Rozwój myśli przedstawicieli oświecenia spowodował zmianę postrzegania przestępstwa bluźnierstwa. Bóg przestał być przedmiotem ochrony prawnej, jednak nadal w kodyfikacjach karnych tej epoki bluźnierstwo było surowo karane. Dopiero Kodeks karny z 1787 r. wprowadzony przez cesarza Józefa II przewidywał miej dotkliwe kary za bluźnierstwo ${ }^{6}$. We Francji zaprzestano ścigania bluźnierców od 1766 r.

\footnotetext{
4 W. Wasil, Od bluźnierstwa..., s. 204.

5 A. Draguła, Bluźnierstwo. Między grzechem a przestępstwem, Warszawa 2013, s. 175.

6 W. Wasil, Od bluźnierstwa..., s. 206.
} 
Deklaracja Praw Człowieka i Obywatela z 1789 r. nie odnosiła się do bluźnierstwa ${ }^{7}$. W trakcie trwania rewolucji francuskiej, pod wpływem doktryny ówczesnych przedstawicieli epoki, doprowadzono do usunięcia przestępstwa bluźnierstwa z prawa francuskiego w $1791 \mathrm{r} .{ }^{8}$ Po upadku Napoleona do prawa francuskiego na mocy ustaw z dnia 17 maja 1819 r. tzw. lois de Serre wprowadzono przestępstwo zniewagi moralności religijnej „outrage à la morale religieuse" ${ }^{\prime \prime}$. Od XIX w. kodeksy państw europejskich liberalizowały kary wymierzane bluźniercom ${ }^{10}$.

\section{Przepisy karne ustawy o wolności prasy}

Przepisy karne zawarte w ustawie z dnia 29 lipca 1881 r. o wolności prasy zmieniły podmiot ochrony z Boga na prawo ludzi do manifestowania swoich przekonań. Ta zmiana była podyktowana w dużym stopniu zmianą podejścia społeczeństwa do religii. Trafnie tę tendencję legislacyjną, obecną także w innych państwach, określił J. Warylewski:

Stanowisko, jakie zajmuje dane ustawodawstwo wobec przestępstw, które najogólniej nazwać by można religijnymi, zależy w dużym stopniu od stanowiska zasadniczego, jakie zajmuje dane społeczeństwo w stosunku do religii ${ }^{11}$.

7 Nikt nie powinien być niepokojony z powodu swoich przekonań, także religijnych pod warunkiem, że ich wyrażanie nie zakłóca porządku publicznego ustanowionego na podstawie ustawy. Zob. art. 10. Deklaracji Praw Człowieka i Obywatela z dnia 26 sierpnia 1789 r.

8 I. Riassetto, Religion et droit penal en France, w: Religion and criminal law, red. M. Kotiranta, N. Doe, Leuven 2013, s. 75.

9 Art 8. Każda zniewaga moralności publicznej i religijnej oraz dobrych obyczajów poprzez jeden ze środków wymienionych w art. 1 podlega karze od jednego miesiąca do roku pozbawienia wolności oraz karze grzywny od 16 do 500 franków. Loi du 17 mai 1819 lois de Serre. Zob. M. Sacquin, Entre Bossuet et Maurras: l'antiprotestantisme en France de 1814 à 1870, Mémoires et Documents de L'École des Chartes, Paris 1998, s. 14.

10 A. Okrzesik, Bluźnierstwo. W prawie świeckim, w: Encyklopedia Katolicka, t. 2..., kol. 672-673.

11 J. Warylewski, Pasja czy obraza uczuć religijnych? Spór wokót art. 196 Kodeksu karnego, w: Wkręgu teorii i praktyki prawa karnego. Księga poświęcona pamięci Profesora Andrzeja Wąska, red. L. Leszczyński, E. Skrętowicz, Z. Hołda, Lublin, s. 367-383. 
We Francji laickość jest traktowana od czasów rewolucji jako nieodłączna wartość republikańskiej formy rządów, następnie zaczynając od czasów III Republiki, stała się ona zasadą prawną. Z kolei ustawa z 1905 r. o rozdziale kościołów od państwa uznała laickość za zasadę konstytucyjną. W praktyce idea laickości nie jest wyłącznie dziedzictwem rewolucji francuskiej, lecz koncepcją filozoficzną o charakterze uniwersalnym. Idea laickości zakłada zagwarantowanie praw fundamentalnych, także religijnych. Oznacza to prawną ochronę wolności: myśli, opinii, wypowiedzi, wierzeń, sumienia, manifestowania swoich przekonań. Zabroniona jest każda forma dyskryminacji z powodu przekonań lub religii. Państwo w świetle powyższego ma za zadanie chronić pluralizm poglądów i zapewnić równość wobec wszystkich przekonań religijnych ${ }^{12}$.

Zmiana ochrony prawnej przedmiotu czci religijnej nastąpiła we Francji w 1881 r. Karalność zachowań noszących znamiona bluźnierstwa, w szerszym niż tylko religijnym zakresie, stała się zależna od skandalu wywołanego obrazą podmiotu lub przedmiotu czci religijnej danej społeczności, a także od formy, jaką ta obraza przybrała.

Pierwotny tekst ustawy z dnia 29 lipca 1881 r. o wolności prasy nie zawierał przepisów bezpośrednio odnoszących się do zniesławienia religijnego ${ }^{13}$. Dopiero na mocy ustawy z dnia 1 lipca 1972 r. wprowadzono do systemu prawa karnego nowy występek określany jako zniesławienie religijne - „la diffamation religieuse"14.

Stosownie do definicji zniesławienia zawartej w art. 29 ustawy o wolności prasy: „Wszelkie zarzuty lub pomówienia mogące zaszkodzić honorowi lub reputacji osoby lub podmiotu, do której są skierowane, stanowią zniesławienie". Bezpośrednie publikowanie lub powielanie takiego zarzutu lub pomówień, które mogą zaszkodzić honorowi lub reputacji, podlega karze, nawet jeżeli jest dokonywane w wątpliwej formie lub jest skierowane do osoby lub podmiotu, który nie został wyraźnie określony,

12 C. Benelbaz, Le principe de laïcité en droit public français, Paris 2011, s. 34-37.

13 Zob. Art 32. La diffamation commise envers les particuliers, par l'un des moyens énoncés en l'article 23 et en l'article 28 , sera punie d'un emprisonnement de cinq jours à six mois et d'une amende de 25 francs à 2.000 francs ou de l'une de ces deux peines seulement. Journal Officiel, 30 juillet 1881, nr 206, p. 4201. [Dziennik Ustaw z 30 lipca 1881 roku, nr 206, s. 4201].

14 Loi n ${ }^{\circ} 72-546$ du 1 juillet 1972 relative à la lutte contre le racism, JORF n0154 du 2 juillet 1972, p. 6803. [Ustawa nr 72-546 z dnia 1 lipca 1972 dotycząca walki z rasizmem, Dziennik Ustaw nr 0154 z 2 lipca 1972, s. 6803]. 
ale możliwy do zidentyfikowania na podstawie określeń użytych w wypowiedzi, okrzykach, groźbach, pismach lub wydrukach, tabliczkach lub plakatach ${ }^{15}$. Przestępstwo zniesławienia podlega karze grzywny stosownie do przepisów art. 29-35 ustawy z dnia 29 lipca 1881 r. o wolności prasy. Karalna jest również zniewaga, którą art. 29 ustawy o wolności prasy definiuje jako „Każde oburzające wyrażenie, słowo pogardy lub inwektywy, które nie zawierają przypisania jakiegokolwiek faktu"16.

Aktualnie przepis art. 32 ustawy o wolności prasy brzmi:

Zniesławienie popełnione poprzez jeden ze środków wymienionych w art. 23 podlega karze 12.000 euro. Zniesławienie popełnione tymi samymi środkami wobec osoby lub grupy osób ze względu na ich pochodzenie lub przynależność lub brak przynależności do danej grupy etnicznej, narodowej, rasowej lub o innej religii, podlega karze jednego roku pozbawienia wolności oraz karze grzywny w wysokości 45.000 euro lub tylko jednej z tych dwóch kar ${ }^{17}$.

Przestępstwo zniesławienia istnieje tylko wtedy, gdy zarzut jest skierowany przeciwko osobie fizycznej lub prawnej i jest wystarczający do zidentyfikowania tej osoby. Od 2000 r. tylko przepisy karne ustawy o wolności prasy mają zastosowanie w kwestiach nadużycia wolności słowa, co wiąże się z przyjęciem uchwały zgromadzenia plenarnego Sądu Kasacyjnego

15 Art. 29. Toute allégation ou imputation d'un fait qui porte atteinte à l'honneur ou à la considération de la personne ou du corps auquel le fait est imputé est une diffamation. La publication directe ou par voie de reproduction de cette allégation ou de cette imputation est punissable, même si elle est faite sous forme dubitative ou si elle vise une personne ou un corps non expressément nommés, mais dont l'identification est rendue possible par les termes des discours, cris, menaces, écrits ou imprimés, placards ou affiches incriminés.

16 Art. 29. Toute expression outrageante, termes de mépris ou invective qui ne renferme l'imputation d'aucun fait est une injure.

17 Art. 32. La diffamation commise envers les particuliers par l'un des moyens énoncés en l'article 23 sera punie d'une amende de 12000 euros. La diffamation commise par les mêmes moyens envers une personne ou un groupe de personnes à raison de leur origine ou de leur appartenance ou de leur non-appartenance à une ethnie, une nation, une race ou une religion déterminée sera punie d'un an d'emprisonnement et de 45000 euros d'amende ou de l'une de ces deux peines seulement. Sera punie des peines prévues à l'alinéa précédent la diffamation commise par les mêmes moyens envers une personne ou un groupe de personnes à raison de leur sexe, de leur orientation sexuelle ou identité de genre ou de leur handicap. En cas de condamnation pour l'un des faits prévus par les deux alinéas précédents, le tribunal pourra en outre ordonner: $1^{\circ} \mathrm{L}^{\prime}$ affichage ou la diffusion de la décision prononcée dans les conditions prévues par l'article 131-35 du code pénal; $2^{\circ}$ (Abrogé). 
w tej materii. Sąd Kasacyjny zdecydował, że „nadużycia wolności wypowiedzi przewidziane i penalizowane przez ustawę z 29 lipca 1881 roku o wolności prasy nie mogą być dochodzone na podstawie artykułu 1382 kodeksu cywilnego"18.

W praktyce usunięcie bluźnierstwa $\mathrm{z}$ francuskiego systemu prawa karnego nie oznacza, że znieważanie przedmiotu czci religijnej stało się bezkarne. Przepisy ustawy o wolności prasy przewidują karalność takich zachowań, które są wymierzone w osoby wierzące z powodu ich przynależności religijnej. Penalizacji podlegają także takie zachowania, które są ukierunkowane na prowokację względem takich osób. Na mocy przepisów ustawy o wolności prasy ochronie nie podlega przedmiot czci religijnej, lecz osoby, które z powodu wyznawanych zasad religijnych są szykanowane, wyszydzane lub w inny sposób dyskryminowane. Ta różnica wydaje się subtelna, ale ma fundamentalne znaczenie. Dobrem chronionym prawnie jest wolność od dyskryminacji z uwagi na przynależność lub jej brak do danej wspólnoty, także religijnej. System francuskiego prawa karnego przewiduje ochronę prawną swobodnego wyrażania myśli, jak również ochronę osób przed prześmiewczym, dyskryminacyjnym traktowaniem z powodu wyznawanych przez nie przekonań religijnych. Co do zasady ustawa z dnia 29 lipca 1881 r. o wolności prasy chroni określone kategorie osób przed zniesławieniem lub zniewagą z uwagi na pełnione przez nie funkcje lub wyznawane przekonania ${ }^{19}$.

Aktualnie rozdział czwarty ustawy o wolności prasy poświęcony jest przestępstwom popełnionym za pomocą prasy lub jakichkolwiek innych publikacji ${ }^{20}$. Przepis art. 23 ustawy penalizuje zachowania polegające na celowym sprowokowaniu sprawcy (autora lub autorów publikacji) do

18 Cour de Cassation, Assemblée plénière, Legipresse 200, nr 175, III, s. 153. [Sąd Kasacyjny, Zgromadzenie Plenarne, Legipresse 200, nr 175, III, s. 153].

19 Art. 37. L'outrage commis publiquement envers les ambassadeurs et ministres plénipotentiaires, envoyés, chargés d'affaires ou autres agents diplomatiques accrédités près du gouvernement de la République, sera puni d'une amende de 45000 euros. [art. 37. Zniewaga popełniona publicznie przeciwko ambasadorom i pełnomocnym reprezentantom, wysłannikom, chargés d'affaires lub innym pracownikom dyplomatycznym akredytowanym przez rząd Republiki będzie podlegać karze 45000 euro].

${ }_{20}$ Code penal. Chapitre IV: Des crimes et delits commis par la voie de la presse ou par tout autre moyen de publication. [Rozdział IV: Przestępstwa i występki popełnione za pomocą prasy lub za pomocą środków społecznego przekazu], https://www.legifrance. gouv.fr/affichCode.do?cidTexte=LEGITEXT000006070719. 
działania za pomocą środków społecznego przekazu, jeśli po prowokacji nastąpił określony skutek. Popełnienie przestępstwa może nastąpić poprzez szereg czynności, takich jak: przemówienia, okrzyki lub groźby $\mathrm{w}$ miejscach publicznych lub na spotkaniach bądź za pomocą pisma, druku, rysunków, grawerów, obrazów, emblematów, zdjęć lub innych środków masowego przekazu, mowy lub obrazu sprzedawanego lub rozpowszechnionego, oferowanego do sprzedaży lub prezentowanego w miejscach lub na zebraniach publicznych, za pomocą plakatów lub afiszy wystawianych publicznie lub za pomocą jakichkolwiek środków komunikacji publicznej drogą elektroniczną ${ }^{21}$.

Przepis art. 24 ustawy o wolności prasy przewiduje sankcję karną pozbawienia wolności do lat pięciu i karę grzywny w wysokości 45000 euro dla tych, którzy za pomocą jednego ze środków wymienionych w art. 23 ustawy o wolności prasy bezpośrednio sprowokowali kogoś do działania, choćby prowokacja nie nastąpiła, a doszło do popełnienia jednego z przestępstw określonych w księdze II Kodeksu karnego (dalej: k.k.).

Podlegają tym samym sankcjom karnym ci, którzy w ten sam sposób bezpośrednio sprowokowali jedno z przestępstw naruszających podstawowe interesy narodu, o których mowa w tytule I księgi IV k.k. Penalizacją objęte są także czyny polegające na podżeganiu do popełnienia przestępstw za pomocą jednego ze sposobów określonych w art. 23 ustawy o wolności prasy.

Za czyny niedozwolone przepis art. 24 ustawy uznaje działania, które w jakikolwiek sposób określony w art. 23 tej ustawy będą prowokować do dyskryminacji, nienawiści lub przemocy wobec osoby lub grupy osób z powodu pochodzenia lub za przynależność do grupy etnicznej, narodu, rasy bądź określonej religii albo z powodu braku przynależności osoby lub grupy osób do grupy etnicznej, narodu, rasy lub określonej religii zostanie skazany na rok pozbawienia wolności i grzywnę w wysokości 45000 euro bądź tylko jedną z tych dwóch kar. Czynem niedozwolonym

${ }^{21}$ Art. 23. Seront punis comme complices d'une action qualifiée crime ou délit ceux qui, soit par des discours, cris ou menaces proférés dans des lieux ou réunions publics, soit par des écrits, imprimés, dessins, gravures, peintures, emblèmes, images ou tout autre support de l'écrit, de la parole ou de l'image vendus ou distribués, mis en vente ou exposés dans des lieux ou réunions publics, soit par des placards ou des affiches exposés au regard du public, soit par tout moyen de communication au public par voie électronique, auront directement provoqué l'auteur ou les auteurs à commettre ladite action, si la provocation a été suivie d'effet. Loi du 29 juillet 1881 sur la liberté de la presse. 
są także działania, poprzez które wywołuje się nienawiść lub przemoc wobec osoby bądź grupy osób ze względu na płeć, orientację seksualną albo tożsamość płciową lub niepełnosprawność. Karalności podlega także każdy, kto spowodowałby, w odniesieniu do osoby lub grupy osób, dyskryminację przewidzianą $\mathrm{w}$ art. 225-2 i 432-7 k.k.

Dodatkowo art. 24 przewiduje dodatkowe środki karne w przypadku skazania za jeden z czynów przewidzianych w art. 23 i 24 cytowanej ustawy. Są to: pozbawienie praw wymienionych w art. 131-26 k.k. maksymalnie przez okres pięciu lat w związku z treścią ustawy nr 82-652 z dnia 29 lipca 1982 r. o komunikacji audiowizualnej; upublicznienie lub rozpowszechnianie wydanego orzeczenia zgodnie $\mathrm{z}$ warunkami przewidzianymi w art. 131-35 k.k. oraz odbycie stażu obywatelskiego przewidzianego w art. 131-5-1 k.k.22

\section{Ochrona prawna przekonań religijnych}

We Francji większość oskarżeń opierających się na zarzucie naruszenia przekonań religijnych dotyczyła przepisów art. 23, 24 i 32 ustawy z dnia 29 lipca 1881 r. o wolności prasy ${ }^{23}$. Przepis art. 24 cytowanej ustawy przewiduje karalność publicznej prowokacji do dyskryminacji, nienawiści lub przemocy wobec osoby lub grupy osób za przynależność do grupy etnicznej, narodu, rasy lub określonej religii bądź z powodu braku przynależności. Karalne jest także usiłowanie popełnienia przestępstwa publicznej prowokacji za pomocą jednego ze środków wymienionych w art. 23 ustawy o wolności prasy, choćby nie nastąpił skutek prowokacji. Stosownie do dyspozycji tego przepisu możliwe jest ukaranie autora wpisu internetowego, jeśli na podstawie jego treści może dojść do dyskryminacji ${ }^{24}$. Stosownie do dyspozycji art. 32 ustawy o wolności

22 Zob. art. 24. Loi du 29 juillet 1881 sur la liberté de la presse.

23 J.L. Capdeville, La protection pénale des minorités religieuses, w: Minorités religieuses, religions minoritaires dans l'espace public, red. A. Zwilling, Strasbourg 2012, s. 44-46.

${ }^{24} \mathrm{~W}$ jednej ze spraw autor wpisu internetowego określił społeczność żydowską jako przeznaczoną do fizycznego wysiedlenia z Europy. Te słowa zostały uznane przez sąd jako usiłowanie prowokacji do dyskryminacji grupy osób z uwagi na ich przynależność religijną. Zob. Chambre criminelle de la Cour de cassation, wyrok z dnia 22 czerwca 2010, sygn. akt 10-82.337: Juris-Data nr 2010-014819. 
prasy karalności podlega publiczne zniesławienie ${ }^{25}$. Reasumując, podając w wątpliwość dogmaty wiary, wyszydzając przedmiot czci religijnej, nie wypełnia się znamion przestępstw określonych w art. 23, 24 i 32 ustawy o wolności prasy. Dopiero intencjonalne wyszydzanie przedmiotów czci religijnej $\mathrm{w}$ powiązaniu $\mathrm{z}$ cechą danej osoby lub grupy osób podlegać będzie karze $^{26}$.

Ustawa z 1905 r. o rozdziale kościołów od państwa gwarantuje każdemu możliwość wyrażania swoich przekonań religijnych w życiu społecznym i publicznym ${ }^{27}$. Przepis art. 32 ustawy z 1905 r. przewiduje karalność dla tych, „którzy przeszkadzaliby, opóźniali lub przerywali wykonywanie praktyk religijnych poprzez zamieszki lub powodowane zakłócanie porządku w lokalu służącym do wykonywania tych praktyk". Ocenie prawnokarnej w jednej ze spraw podlegało zachowanie młodych ludzi, którzy w trakcie mszy świętej wtargnęli do kościoła z twarzami wymalowanymi na wzór zmarłych. W uzasadnieniu orzeczenia sąd ocenił ich zachowanie poprzez naruszenie art. 32 ustawy z 1905 r. jako niebezpieczne

25 Art. 32. Zniesławienie popełnione przeciwko osobom za pomocą jednego ze sposobów określonych w art. 23 zostanie ukarane grzywną w wysokości 12000 euro. Zniesławienie popełnione $\mathrm{w}$ ten sam sposób wobec osoby lub grupy osób z powodu ich pochodzenia, przynależności lub braku członkostwa w określonej grupie etnicznej, narodzie, rasie lub określonej religii będzie karane poprzez jeden rok pozbawienia wolności i grzywną w wysokości 45000 euro lub tylko jedną z tych dwóch kar. Czyny popełnione w ten sam sposób wobec osoby lub grupy osób ze względu na ich płeć, orientację seksualną lub tożsamość płciową lub niepełnosprawność będą podlegać karom przewidzianym w poprzednim ustępie. W przypadku skazania za jeden z czynów przewidzianych w dwóch poprzednich akapitach sąd może również nakazać: $1^{\circ}$ Upublicznienie lub rozpowszechnianie orzeczenia wydanego zgodnie z warunkami przewidzianymi w art. 131-35 Kodeksu karnego; $2^{\circ}$ odbycie stażu obywatelskiego przewidzianego w art. 131-5-1 Kodeksu karnego. Loi du 29 juillet 1881 sur la liberté de la presse.

26 Oto przykłady prawomocnych orzeczeń sądowych $\mathrm{w}$ tego typu sprawach: Chambre criminelle de la Cour de cassation, wyrok z dnia 17 lutego 1998 r., sygn. akt 96-85.567; Chambre criminelle de la Cour de cassation, wyrok z dnia 14 maja 2002 r., sygn. akt 01-85.482: Juris-Data nr 2002-015301; Chambre criminelle de la Cour de cassation, wyrok z dnia 30 maja 2007 r., sygn. akt 06-84.328: Juris-Data nr 2007-039742; Chambre criminelle de la Cour de cassation, wyrok z dnia 3 lutego 2009 r., sygn. akt 08-82.402: Juris-Data nr 2009-046976; Cour d'appel Paris, wyrok z dnia 2 kwietnia 2009 r.: Juris-Data nr 2009-376820; Cour d'appel Toulouse, wyrok z dnia 19 października 2010 r.: Juris-Data nr 2010-029598.

27 C. Benelbaz, Le principe, Paris 2011, s. 417. 
względem osób wierzących i modlących $\operatorname{się}^{28}$. W praktyce sądy często odwołują się w swoich orzeczeniach do konieczności ochrony uczuć religijnych, co przy braku prawnej definicji uczuć religijnych budzi poważne wątpliwości w doktrynie ${ }^{29}$.

Do 2017 r. francuskie prawo karne dokonywało zróżnicowania prawnego na zniesławienie publiczne i niepubliczne ${ }^{30}$. W 2017 r. na mocy przepisów dekretu nr 2005-284 z 25 marca 2005 r. zmieniono brzmienie podrozdziału trzeciego k.k. i nadano mu nową nazwę Prowokacje, zniesławienia i zniewagi o charakterze rasistowskim lub dyskryminacyjnym. Na mocy przepisów tego dekretu, którego nadrzędnym celem było usprawnienie walki z przejawami rasizmu, seksizmu i homofobii mogących wystąpić w miejscach niepublicznych, takich jak firmy lub placówki edukacyjne ${ }^{31}$, wprowadzono szereg zmian legislacyjnych. Uchylono treść dotychczasowych przepisów k.k. (art. 624-3; art. 624-4; art. 624-5; art. 624-6) dokonano zmiany już istniejących (art. 625-7; art. 625-8) i wprowadzono dwa nowe przestępstwa (art. 625-8-1; art. 625-8-2). Dekret wszedł w życie 4 sierpnia 2017 r., a więc następnego dnia po jego opublikowaniu ${ }^{32}$.

Znowelizowany art. 625-7 k.k. przewiduje przestępstwo niepublicznej prowokacji. Przestępstwo można popełnić, gdy sprawca dokona czynności mającej na celu sprowokowanie osoby lub grupy osób do dyskryminacji, nienawiści lub przemocy ze względu na pochodzenie bądź członkostwo lub brak członkostwa, rzeczywiste albo rzekome do grupy etnicznej, narodu, domniemanej rasy lub określonej religii. Tak samo karane są czyny, których celem jest niepubliczne prowokowanie nienawiści lub przemocy wobec osoby bądź grupy osób ze względu na płeć, orientację seksualną

28 Tribunal correctionnel Bar-le-Duc, wyrok z dnia 2 czerwca 1982 r., Witkowski et Lantenois, Gaz. Pal. 1982, nr 2, s. 556.

29 P. Malaurie, Cours de droit civil, les personnes, les incapacites, Paris 1989, s. 328 i 402; T. Massis, La liberté de conscience, le sentiment religieux et le droit pénal, Chron. XXII, Dalloz 1992, s. 113-116.

30 Przed wejściem w życie dekretu nr 2017-1230 z dnia 3 sierpnia 2017 r. podrozdział trzeci Kodeksu karnego brzmiał Zniestawienie i zniewaga niepubliczna mająca charakter rasistowski lub dyskryminacyjny i w pełni oddawał istotę prawnego zróżnicowania zniewag i zniesławień o charakterze publicznym i niepublicznym.

31 Preambuła do dekretu nr 2017-1230 z dnia 3 sierpnia 2017 r. odnoszącego się do prowokacji, zniesławień i zniewag o charakterze rasistowskim lub dyskryminacyjnym, JORF n0182 du 5 août 2017, texte $n^{\circ} 9$.

32 Décret $n^{\circ}$ 2017-1230 du 3 août 2017 relatif aux provocations, diffamations et injures non publiques présentant un caractère raciste ou discriminatoire. NOR: JUSD1714912D. 
albo tożsamość płciową lub niepełnosprawność. Istotą tego przestępstwa jest ochrona osób przed wszelkimi formami dyskryminacji o charakterze niepublicznym, w szczególności w miejscu pracy.

Znowelizowany przepis art. 625-8 k.k. przewiduje karalność za popełnienie przestępstwa zniesławienia o charakterze niepublicznym ${ }^{33}$. Definicja zniesławienia zawarta $\mathrm{w}$ art. 29 ustawy o wolności prasy ma zastosowanie do tego przestępstwa. W świetle art. 625-8 k.k. zniesławieniem będą "wszelkie zarzuty lub pomówienia mogące zaszkodzić honorowi lub reputacji osoby lub podmiotu, do której są skierowane”. Karalności podlegać będą także działania mające na celu bezpośrednie publikowanie lub powielanie nieprawdziwych zarzutów lub pomówień. Tej samej karze grzywny 5. klasy podlega sprawca, który niepubliczne zniesławi osobę lub grupę osób ze względu na płeć, orientację seksualną lub tożsamość płciową bądź niepełnosprawność.

Zaostrzone sankcje karne przewidują, że niepubliczne zniesławienia i zniewagi, podobnie jak prowokacje, będą podlegać sankcji grzywny 5. klasy, wynoszącej maksymalnie stawkę w wysokości 1500 euro lub 3000 euro w przypadku recydywy. Katalog przestępstw został poszerzony o te przestępstwa, które są popełniane z powodu tożsamości płciowej ofiary, w celu lepszego zwalczania transfobii. Pojęcie rasy zostało zastąpione wyrażeniem, "domniemanej rasy", jak to uczyniono w przepisach k.k. ustawą z dnia 27 stycznia 2017 r. ${ }^{34}$

33 Art. 625-8. La diffamation non publique commise envers une personne ou un groupe de personnes à raison de leur origine ou de leur appartenance ou de leur non-appartenance, vraie ou supposée, à une ethnie, une nation, une prétendue race ou une religion déterminée est punie de l'amende prévue pour les contraventions de la 5e classe. Est punie de la même peine la diffamation non publique commise envers une personne ou un groupe de personnes à raison de leur sexe, de leur orientation sexuelle ou identité de genre, ou de leur handicap. [Niepubliczne zniesławienie popełnione na osobie lub grupie osób ze względu na pochodzenie lub przynależność lub brak członkostwa, prawdziwego lub rzekomego do grupy etnicznej, narodu, domniemanej rasy lub określonej religii podlega karze grzywny przewidzianej dla grzywny 5. klasy. Tę samą karę nakłada się za niepubliczne zniesławienie popełnione na osobie lub grupie osób ze względu na płeć, orientację seksualną lub tożsamość płciową lub niepełnosprawność]. Zob. art. 625-8 zmieniony na mocy art. 1 dekretu nr 2017-1230 z dnia 3 sierpnia 2017 r.

34 Preambuła do dekretu nr 2017-1230 z dnia 3 sierpnia 2017 r. odnoszącego się do prowokacji, zniesławień i zniewag o charakterze rasistowskim lub dyskryminacyjnym, JORF n0182 du 5 août 2017, texte $n^{\circ} 9$. 
Na mocy wspomnianego dekretu do k.k. wprowadzono nowy typ przestępstwa. Artykuł 625-8-1 k.k. penalizuje niepubliczną zniewagę. Niepubliczna zniewaga może zostać popełniona na osobie lub grupie ludzi z powodu pochodzenia bądź przynależności lub braku członkostwa, prawdziwego albo rzekomego do grupy etnicznej, narodu, domniemanej rasy lub określonej religii. Tej samej karze podlega, kto popełnia niepubliczne zniewagi przeciwko osobie lub grupie osób ze względu na płeć, orientację seksualną bądź tożsamość płciową lub niepełnosprawnośćn ${ }^{35}$.

Osoby uznane za winne popełnienia przestępstw przewidzianych w art. 625-7, 625-8, 625-8-1, 625-8-2 k.k. ponoszą, oprócz kary grzywy przewidzianej $w$ tych artykułach, następujące dodatkowe kary: zakaz posiadania lub noszenia, przez okres maksymalnie trzech lat, broni wymagającej zezwolenia; konfiskata jednej lub większej liczby broni, których skazany jest właścicielem, lub które posiada do swobodnego użytku; konfiskata rzeczy, która służyła lub miała na celu popełnienie przestępstwa, lub rzeczy, która jest jej wynikiem; praca społeczna przez okres od dwudziestu do stu dwudziestu godzin; obowiązek odbycia stażu obywatelskiego, jeśli to konieczne na jego koszt. Ponowne popełnienie przestępstwa podlega zaostrzonej sankcji karnej zgodnie z art. 132-11 i 132-15 francuskiego k.k. ${ }^{36}$ Znowelizowane przepisy wprowadziły dodatkową sankcję karną stażu

35 Art. 625-8-1. L'injure non publique commise envers une personne ou un groupe de personnes à raison de leur origine ou de leur appartenance ou de leur non-appartenance, vraie ou supposée, à une ethnie, une nation, une prétendue race ou une religion déterminée est punie de l'amende prévue pour les contraventions de la 5e classe. Est punie de la même peine l'injure non publique commise envers une personne ou un groupe de personnes à raison de leur sexe, de leur orientation sexuelle ou identité de genre, ou de leur handicap. [Niepubliczna zniewaga popełniona na osobie lub grupie ludzi z powodu pochodzenia lub przynależności lub braku członkostwa, prawdziwego lub rzekomego do grupy etnicznej, narodu, domniemanej rasy lub określonej religii jest karana grzywną przewidzianą dla grzywny 5. klasy. Ta sama kara nakładana jest za niepubliczne zniewagi popełnione przeciwko osobie lub grupie osób ze względu na płeć, orientację seksualną lub tożsamość płciową lub niepełnosprawność].

36 Art. 132-11. W przypadkach, w których przepisy nie stanowią inaczej, gdy osoba fizyczna, która została już ostatecznie skazana za przestępstwo 5. klasy, popełni w ciągu jednego roku od wygaśnięcia kary lub przedawnienia poprzedniej kary, przy takim samym naruszeniu maksymalna nałożona grzywna zostaje podwyższona do 3000 euro. W przypadkach, w których prawo stanowi, że recydywa naruszenia 5. klasy stanowi przestępstwo, recydywa jest ustalana, jeżeli czyny zostały popełnione $\mathrm{w}$ ciągu trzech lat od wygaśnięcia lub przedawnienia poprzedniej kary. 
obywatelskiego, która obecnie obowiązuje w przypadku przestępstw przewidzianych w ustawie z dnia 29 lipca 1881 r. o wolności prasy ${ }^{37}$.

Celem wspomnianego dekretu było wzmocnienie represji w stosunku do prowokacji, zniesławień i niepublicznych zniewag o charakterze rasistowskim lub dyskryminującym, które mogą wystąpić w miejscach niepublicznych, takich jak firmy lub placówki edukacyjne ${ }^{38}$.

W praktyce znowelizowane przepisy k.k. wzmocniły sankcje karne wobec niepublicznej prowokacji, zniesławiania i zniewagi o charakterze rasistowskim, seksistowskim, homofobicznym lub ze względu na niepełnosprawność na warunkach podobnych do tych przewidzianych w ustawie z 29 lipca 1881 r. o wolności prasy oraz na mocy ustawy nr 2017-86 z dnia 27 stycznia 2017 r. dotyczącej równości i obywatelstwa w odniesieniu do przestępstw prowokacyjnych, zniesławienia oraz rasistowskich lub dyskryminujących zniewag popełnianych w sposób publiczny ${ }^{39}$.

System ochrony prawnej odnosi się do osób przynależących do określonej religii. Przepisy ustawy o wolności prasy oraz przepisy k.k. chronią osoby wierzące (przynależące do określonej religii) oraz niewierzące. Zakres zastosowania tych przepisów odnosi się do wszystkich religii istniejących na terenie Francji, również tych, które nie mają uregulowanej sytuacji prawnej. Ochrona prawna odnosi się także do sekt z tym zastrzeżeniem, że muszą one mieć charakter religijny ${ }^{40}$. Przedmiotem ochrony są wierzenia religijne ${ }^{41}$.

37 Preambuła do dekretu nr 2017-1230 z dnia 3 sierpnia 2017 r. odnoszącego się do niepublicznych prowokacji, zniesławień i zniewag o charakterze rasistowskim lub dyskryminacyjnym, JORF n0182 du 5 août 2017, texte $n^{\circ}$ 9. [Dziennik Ustaw nr 0182 z 5 sierpnia 2017, tekst nr 9].

38 Tamże.

39 Tamże.

40 W jednym z orzeczeń Sąd Apelacyjny w Paryżu określił, że jedną z cech religii jest kryterium jej wiarygodności. Zob. Cour d'appel Paris, wyrok z dnia 25 marca 1996 r.: Juris-Data nr 1996-020719.

41 I. Riassetto, Religion..., s. 76. 


\section{Lokalne prawo karne Alzacji-Mozeli}

Prawo lokalne Alzacji-Mozeli obejmuje swym zasięgiem trzy departamenty (Górny Ren, Dolny Ren, Mozela) i jest szczególnym wyjątkiem, ponieważ ten teren został przyłączony do Cesarstwa Niemieckiego (Deutsches Kaiserreich) w latach 1871-1918, zatem na tym terytorium nie obowiązywała ustawa z dnia 29 lipca 1881 r. o wolności prasy ${ }^{42}$. Niemiecki Kodeks karny (Strafgesetzbuch) z dnia 15 maja 1871 r. zastąpił prawo karne francuskie ${ }^{43}$.

W trzech departamentach: Górnym Renie, Dolnym Renie, Mozeli obowiązywał w latach 1871-1918 następujący przepis prawa karnego przewidujący karalność za zniesławienie wyznań religijnych, organizacji religijnych i stowarzyszeń światopoglądowych:

$\S 166$ ust. 1. Kto publicznie lub przez rozpowszechnianie pism (§ 11 pkt 3) obraża treść wyznania religijnego lub ideologicznego innych osób w sposób, który może zakłócać pokój publiczny, zostanie ukarany karą grzywny lub karą pozbawienia wolności do trzech lat ${ }^{44}$.

$\S 166$ ust 2. Każdy, kto publicznie lub przez rozpowszechnianie pism (§ 11 par. 3) zniesławia, w sposób, który może zakłócić spokój publiczny, uznany kościół w Niemczech lub inne stowarzyszenie religijne lub stowarzyszenie światopoglądowe, lub ich instytucje albo zwyczaje, podlega tej samej karze ${ }^{45}$.

Na mocy dekretu z 25 listopada 1919 r. o pozostawieniu w mocy przepisów karnych ${ }^{46}$ prawo lokalne Alzacji-Mozeli zostało zachowane aż do czasów współczesnych. Specyfika prawna prawa lokalnego polega na tym, że

42 Loi du 29 juillet 1881 sur la liberté de la presse, JORF du 30 juillet 1881, p. 4201. [Ustawa z dnia 29 lipca 1881 r. o wolności prasy, Dziennik Ustaw z 30 lipca 1881 roku, s. 4201].

43 W okresie 1871-1918 na terenie Alzacji i Mozeli obowiązywał Strafgesetzbuch. F. Messner, Code pénal local (Alsace-Moselle), w: Droit des religions en France et en Europe: Recueil de textes, red. F. Curtit, F. Messner, Bruxelles 2008, s. 345-346.

44 Wer öffentlich oder durch Verbreiten von Schriften (§ 11 Abs. 3) den Inhalt des religiösen oder weltanschaulichen Bekenntnisses anderer in einer Weise beschimpft, die geeignet ist, den öffentlichen Frieden zu stören, wird mit Freiheitsstrafe bis zu drei Jahren oder mit Geldstrafe bestraft. Zob. § 166 ust. 1 Strafgesetzbuch.

45 Ebenso wird bestraft, wer öffentlich oder durch Verbreiten von Schriften (§ 11 Abs. 3) eine im Inland bestehende Kirche oder andere Religionsgesellschaft oder Weltanschauungsvereinigung, ihre Einrichtungen oder Gebräuche in einer Weise beschimpft, die geeignet ist, den öffentlichen Frieden zu stören. Zob. \$166 ust. 2 Strafgesetzbuch.

${ }^{46}$ Décret du 25 novembre 1919 sur le maintien de dispositions pénales. 
na tym terenie obowiązują następujące przepisy prawa: prawo francuskie sprzed 1870 r., które nie zostało uchylone przez przepisy prawne Cesarstwa Niemieckiego z tym zastrzeżeniem, że aktualnie władze francuskie mogą te przepisy zmienić lub uchylić; prawo niemieckie z okresu Cesarstwa Niemieckiego (1871-1918); przepisy prawa lokalnego uchwalone przez właściwe organy lokalne na terenie trzech departamentów; niektóre przepisy prawa francuskiego uchwalone w okresie 1871-1918, a następnie pozostawione $\mathrm{w}$ mocy na podstawie ustawy z 1 czerwca $1924 \mathrm{r} \cdot{ }^{47}$ oraz przepisy prawa francuskiego uchwalane po 1918 r. odnoszące się wyłącznie do tych trzech departamentów ${ }^{48}$.

Ustawa z dnia 9 grudnia 1905 r. o rozdziale kościołów od państwa nie jest stosowana w trzech departamentach: Górnym Renie, Dolnym Renie, Mozeli pomimo formalnego jej obowiązywania. Specyfika prawna prawa lokalnego opiera się na prawnym uznaniu czterech religii: katolickiej, ewangelicko-augsburskiej, ewangelicko-reformowanej, mojżeszowej. Podstawę prawną takiego stanu rzeczy stanowią przepisy ustawy z 18 germinal roku X, które zmieniły przepisy Konkordatu ze Stolicą Apostolską z dnia 10 września 1801 r. oraz przepisy tzw. Artykułów Organicznych odnoszących się do sytuacji prawnej Kościoła katolickiego i Kościoła ewangelicko-augsburskiego oraz ewangelicko-reformowanego. Z kolei przepisy dwóch dekretów z dnia 17 marca 1808 r. o organizacji kultu mojżeszowego odnoszą się bezpośrednio do sytuacji prawnej tego związku wyznaniowego ${ }^{49}$.

Formalne obowiązywanie ustawy z dnia 9 grudnia 1905 r. nie stoi w sprzeczności z uznaniem czterech wymienionych powyżej wyznań za oficjalne, powoduje jednak konieczność ograniczenia jej obowiązywania. Poza czterema oficjalnymi religiami pozostałe związki wyznaniowe nie podlegają pod przepisy ustawy z 1905 r., gdyż nie byłoby możliwe utrzymywanie dwóch porządków prawnych $w$ tak skrajnej postaci. $Z$ tego powodu pozostałe związki wyznaniowe, również nowopowstałe, podlegają

47 Loi du 1er juin 1924 mettant en vigueur la législation civile française dans les départements du Bas-Rhin, du Haut-Rhin et de la Moselle, JORF n0151 du 3 juin 1924, p. 5026. [Ustawa z 1 czerwca 1924 o utrzymaniu w mocy ustawodawstwa cywilnego francuskiego w departamentach Dolny Ren. Górny Ren, Mozela, Dziennik Ustaw nr 0151 z 3 czerwca 1924, s. 5026].

48 Conseil constitutionnel, Décision n²011-157 QPC du 5 août 2011 (Société SOMODIA).

49 F. Messner, Code pénal local..., s. 345-347. 
pod przepisy prawa cywilnego lokalnego i mogą funkcjonować $\mathrm{w}$ formie stowarzyszeń ${ }^{50}$.

Prawo lokalne Alzacji-Mozeli na mocy ustawy z dnia 1 czerwca 1924 r. ${ }^{51}$ stało się częścią prawa francuskiego. Od 1919 r. do prawa lokalnego mają zastosowanie wszystkie przepisy prawa francuskiego. W okresie Trzeciej Rzeszy (1939-1945) prawo lokalne zostało usunięte z systemu prawa francuskiego, ale na mocy rozporządzenia z dnia 15 września 1944 r. ${ }^{52}$ przywrócono jego obowiązywanie ${ }^{53}$.

Rada Stanu wielokrotnie dokonywała oceny zgodności odrębności prawnej trzech departamentów z konstytucyjną zasadą świeckości państwa $^{54}$. W jednym z orzeczeń Rada Stanu bardzo klarownie wyraziła stanowisko na temat obowiązywania prawa lokalnego we francuskim systemie prawnym, stwierdzając, że zasada świeckości państwa nie uchyla automatycznie przepisów prawa lokalnego ${ }^{55}$. Ten swoisty dualizm funkcjonowania dwóch porządków prawnych na tym samym terytorium powoduje liczne problemy w zakresie zastosowania właściwego prawa przez sądy ${ }^{56}$.

${ }^{50} \mathrm{~W}$ trzech departamentach Alzacji-Mozeli wciąż obowiązuje dla czterech religii uznanych przez państwo szereg uprawnień publicznoprawnych, w tym dofinansowanie do działalności kultu religijnego, nauczanie religii w szkole podstawowej i ponadpodstawowej, finansowanie wydziału teologii protestanckiej i katolickiej na uniwersytecie w Strasburgu, finansowanie pensji kapelanów w szpitalach i wojsku z budżetu państwa. F. Messner, Code pénal local..., s. 347.

51 Loi du 1er juin 1924 mettant en vigueur la législation civile française dans les départements du Bas-Rhin, du Haut-Rhin et de la Moselle, JORF n0151 du 3 juin 1924, p. 5026.

${ }^{52}$ Ordonnance du 15 septembre 1944 relative au rétablissement de la légalité républicaine dans les départements du Bas-Rhin, du Haut-Rhin et de la Moselle, JORF du 16 septembre 1944, p. 814.

53 F. Messner, Code pénal local..., s. 346.

54 Conseil d’État, assemblée, 22 janvier 1988, Association Les Cigognes, n 80936; Conseil d'État, 17 mai 2002, Hofmann, n 231290.

55 "Considérant que l'article 7 de la loi du 1er juin 1924, mettant en vigueur la législation civile française dans les départements du Haut-Rhin, du Bas-Rhin et de la Moselle, a maintenu en application dans ces départements les articles 21 à 79 du code civil local; qu'ainsi le maintien en vigueur de la législation locale procède de la volonté du législateur; que si, postérieurement à la loi précitée du 1er juin 1924, les préambules des constitutions des 27 octobre 1946 et 4 octobre 1958 ont réaffirmé les principes fondamentaux reconnus par les lois de la République, au nombre desquels figure le principe de laïcité, cette réaffirmation n'a pas eu pour effet d'abroger implicitement les dispositions de ladite loi". Zob. Conseil d'État, 6 avril 2001, SNES, nº 219379221699221700.

56 I. Riassetto, Religion..., s. 75. 
Do 2017 r. przepis art. 166 lokalnego prawa karnego stanowił, że

Ten, kto wywołuje skandal, publicznie bluźniąc przeciwko Bogu poprzez znieważenie lub publicznie obrażając chrześcijańskie kulty lub wspólnotę religijną założoną na terytorium Konfederacji i uznawaną za korporację lub instytucje oraz ceremonie tych kultów lub ten, kto w kościele lub innym miejscu poświęconym spotkaniom religijnym, popełni szkodliwe i skandaliczne czyny będzie ukarany karą pozbawienia wolności nie mniej niż trzy lata ${ }^{57}$.

Karze podlegał każdy, kto bluźnił przeciwko Bogu w miejscach publicznych, a także kto mógł znieważyć lub obrazić uczucia religijne związane z wykonywaniem kultu religijnego. Znieważyć można było także miejsca przeznaczone do wykonywania praktyk religijnych. Przepis zawierał wymóg wywołania publicznego skandalu. Przewidywał także możliwość przestępstwa obrazy religii (cultes chrétiens) lub wspólnoty religijnej (une communauté religieuse), obrzędów religijnych, przedmiotu czci religijnej. Zakres przedmiotowy tego przestępstwa dotyczył bluźnierstwa przeciwko Bogu, znieważenia wyznań i dogmatów religijnych (chrześcijańskich), a także znieważenia miejsc kultu religijnego w szerokim rozumieniu tego słowa jako każde miejsce przeznaczone do zgromadzeń religijnych.

Ochronie prawnej z art. 166 lokalnego Kodeksu karnego Alzacji-Mozeli podlegały cztery religie uznane za oficjalne: rzymskokatolicka, protestancka (wyznanie ewangelicko-reformowane, wyznanie ewangelicko-augsburskie) oraz judaizm. Islam stanowiący drugą religię we Francji pod względem wyznawców nie podlegał ochronie prawnej tego przepisu. Ten stan rzeczy wynikał z faktu obowiązywania na tym terenie przepisów Konkordatu zawartego przez Napoleona w 1801 r. wraz z artykułami organicznymi stanowiącymi integralną część tego Konkordatu ${ }^{58}$. Natomiast przepis art. 167 lokalnego prawa karnego Alzacji-Mozeli penalizował do 2017 r. czyny polegające na przeszkadzaniu w wykonywaniu aktów

57 W oryginale art. 166 brzmi „celui qui aura causé un scandale en blasphémant publiquement contre Dieu par des propos outrageants ou aura publiquement outragé un des cultes chrétiens ou une communauté religieuse établie sur le territoire de la Confédération et reconnue comme corporation ou les institutions ou cérémonies de ces cultes ou qui, dans une église ou un autre lieu consacré à des assemblées religieuses, aura commis des actes injurieux et scandaleux sera puni d'un emprisonnement de trois ans au plus". Tekst dostępny w: F. Messner, Code pénal local..., s. 492-493.

58 Tamże, s. 347. 
kultu religijnego ${ }^{59}$. Po II wojnie światowej dochodziło $\mathrm{w}$ trzech departamentach: Górnym Renie, Dolnym Renie i Mozeli do skazywania osób na mocy art. 167 lokalnego prawa karnego. Sąd w Colmar w 1954 r. odmówił zastosowania art. 166 lokalnego prawa karnego w konkretnej sprawie ${ }^{60}$.

Obowiązywanie art. 166 lokalnego prawa karnego napotykało na trudności, gdyż ustawa z 1 czerwca 1924 r. wprowadziła również do prawa lokalnego Alzacji-Mozeli ustawę z 29 lipca 1881 r. Dyspozycja art. 166 lokalnego prawa karnego nie została oficjalnie implementowana do prawa francuskiego. W praktyce oznaczało to, że powstały na tym terenie dwa reżimy prawne: przepisy karne ustawy o wolności prasy, które nie przewidywały przestępstwa bluźnierstwa, oraz przepisy lokalnego prawa karnego, które przewidywały m.in. przestępstwo bluźnierstwa przeciwko Bogu. Przepisy lokalnego prawa karnego, w tym ten dotyczący bluźnierstwa, nie zostały przetłumaczone na język francuski, co powodowało niemożliwość jego zastosowania przez sądy w Strasbourgu i Metz. Oficjalnego tłumaczenia aktów prawnych obowiązujących w trzech departamentach: Górnym Renie, Dolnym Renie, Mozeli na język francuski dokonano dopiero w 2013 r. na podstawie dwóch dekretów ${ }^{61}$. Od tego czasu sądy nie otrzymały do rozpatrzenia żadnej sprawy podlegającej pod art. 166 i art. 167 lokalnego prawa karnego.

Dyskusja na temat obowiązywania przepisu dotyczącego bluźnierstwa została wznowiona po ataku 7 stycznia 2015 r. w siedzibie magazynu satyrycznego „Charlie Hebdo”. Kilka dni po ataku na Charlie Hebdo masoni Wielkiego Wschodu Francji zadeklarowali, że „należy dołożyć wszelkich starań, aby zbrodnia bluźnierstwa, która nadal istnieje na terytorium Alzacji-Mozeli, została usunięta bez zwłoki" ${ }^{62}$. W tym samym czasie senator-burmistrz Woippy François Grosdidier złożył projekt

59 Art. 167. Ten, kto przez napaść lub groźbę uniemożliwia oddawanie czci osobie wspólnoty religijnej uznanej w państwie lub kto w kościele lub innym miejscu przeznaczonym do zgromadzeń religijnych uniemożliwia lub przeszkadza poprzez zakłócenie lub nieporządek, dobrowolne nabożeństwo lub niektóre ceremonie kultu wspólnoty religijnej ustanowionej w państwie, podlega karze pozbawienia wolności co najmniej trzy lata.

60 Cour d'Appel Colmar; 19 nov. 1954, Pferdzer et Sobezac; Cass. 30 nov. 1999, Fromm et autres.

61 Décret n²013-395 du 14 mai 2013 oraz décret n 2013-776 du 27 août 2013.

62 Le Sénat supprime le délit de blasphème qui s'applique en Alsace-Moselle, http:/ / www.patronagelaique.fr/index.php/ressources/telechargements/354-le-senat-supprime-le-delit-de-blaspheme-qui-s-applique-en-alsace-moselle (dostęp: 10.01.2020 r.). 
ustawy o zniesieniu bluźnierstwa. Jak widać na przedstawionym przykładzie, aktywność polityczna różnego rodzaju organizacji światopoglądowych we Francji oraz podejście elit rządzących ma realny wpływ na kształt prawa francuskiego, a co za tym idzie - na promocję idei państwa świeckiego. Jedyną aktywnością społeczno-polityczną w kraju mającą na celu ochronę religii wykazała się Liga Obrony Sądowej Muzułmanów, która m.in. w 2015 r. oburzona karykaturą opublikowaną w "Charlie Hebdo" wezwała, by zaatakować satyryczny tygodnik przed dworcem w Strasburgu $^{63}$. Wyznawcy pozostałych religii nie byli aktywni w trakcie debaty parlamentarnej i nie wyrażali sprzeciwu wobec aktów agresji i przemocy względem ich religii. Co ciekawe, 6 stycznia 2015 r., w przededniu krwawego ataku na "Charlie Hebdo”, przedstawiciele czterech uznanych religii w Alzacji-Mozeli opowiadali się podczas spotkania przed Observatoire de la laïcité, za uchyleniem przestępstwa bluźnierstwa ${ }^{64}$.

W 2015 r. minister sprawiedliwości udzielił odpowiedzi na pytanie senatorów, wskazując, że art. 166 lokalnego prawa karnego został już dawno uchylony wskutek desuetudo, a także z uwagi na to, że jest sprzeczny $\mathrm{z}$ fundamentalnymi zasadami prawa francuskiego ${ }^{65}$. W odpowiedzi na atak terrorystyczny, który miał miejsce 7 stycznia 2015 r. w siedzibie magazynu satyrycznego "Charlie Hebdo", francuski parlament uchylił ostatecznie przepis dotyczący bluźnierstwa (art. 166 lokalnego prawa karnego) na mocy ustawy z dnia 27 stycznia 2017 r. o równości i obywatelstwie ${ }^{66}$.

63 J. Klur, En Alsace-Moselle, le blasphème reste interdit et fait polémique, Le Journal du Dimanche, https://www.lejdd.fr/Societe/Religion/En-Alsace-Moselle-le-blaspheme-resteinterdit-et-fait-polemique-principalement-au-sein-du-Conseil-regional-du-culte-musulman-714182 (dostęp: 10.01.2020 r.).

64 Premier Ministre, Avis sur le régime local des cultes en Alsace et en Moselle, Paris, le mardi 12 mai 2015, https:/ / www.gouvernement.fr/sites/default/files/contenu/piecejointe/2015/05/avis_alsace-moselle_definitif.pdf (dostęp: 10.10.2019 r.).

65 Réponse du Ministère de la justice publiée dans le JO Sénat du 17/12/2015, p. 3486. [Odpowiedź Ministra Sprawiedliwości opublikowana dnia 17.12.2015 w Dzienniku Urzędowym Senatu].

66 Art. 172. Le code pénal local applicable dans les départements du Bas-Rhin, du Haut-Rhin et de la Moselle est ainsi modifié: $1^{\circ}$ L'article 166 est abrogé; $2^{\circ}$ L'article 167 est ainsi rédigé: “Art. 167. - Les articles 31 et 32 de la loi du 9 décembre 1905 concernant la séparation des Eglises et de l'Etat sont applicables". [Kodeks karny lokalny mający zastosowanie w departamentach Dolny Ren, Górny Ren i Mozela zostaje zmieniony: $1^{\circ}$ art. 166 jest uchylony; art. 167 zostaje zmieniony: „,art. 167. Artykuły 31 i 32 ustawy z dnia 9 grudnia 1905 roku o rozdziale kościołów od państwa mają zastosowanie”]. Loi n² 2017-86 du 
Natomiast art. 167 lokalnego prawa karnego został zmieniony ${ }^{67}$. Nadal w trzech departamentach: Górnym Renie, Dolnym Renie, Mozeli obowiązuje przepis lokalnego prawa karnego (art. 130a ${ }^{68}$. Zakres przedmiotowy tego przestępstwa dotyczy wywołania przez duchownego publicznego nieporządku wskutek jego działalności religijnej o charakterze antypaństwowym.

W 2017 r. parlament dokonał depenalizacji przestępstwa bluźnierstwa w trzech departamentach: Górnym Renie, Dolnym Renie, Mozeli, na co wpływ miała bierność lokalnej społeczności. Zupełnie odwrotna sytuacja miała miejsce po II wojnie światowej, gdy opór lokalnej społeczności doprowadził do utrzymania w mocy przepisów lokalnego prawa karnego. Zauważyć można, że władze publiczne przeforsowały zmiany legislacyjne, mając na celu zabezpieczenie społeczeństwa przed zakłóceniem porządku publicznego. $W$ dyskusji nad uchyleniem tych przepisów nie brano pod uwagę odczuć religijnych osób wierzących. W trakcie prac parlamentarnych rząd przedstawiał projekt ustawy, która de facto miała na celu uchylenie przestępstwa bluźnierstwa jako krok mający na celu obronę Francuzów, którzy mają wolę do życia w społeczeństwie otwartym, gdzie wolność wypowiedzi nie może być niczym skrępowana ${ }^{69}$.

27 janvier 2017 relative à l'égalité et à la citoyenneté, JORF n0024 du 28 janvier 2017, texte $\mathrm{n}^{\circ}$ 1. [Ustawa nr 2017-86 z dnia 27 stycznia 2017 r. Dotycząca równosci i obywatelstwa, Dziennik Ustaw nr 0024 z 28 stycznia 2017, tekst nr 1].

67 Po nowelizacji art. 167 lokalnego prawa karnego brzmi „Artykuły 31 i 32 ustawy z dnia 9 grudnia 1905 roku o rozdziale kościołów od państwa mają zastosowanie”. Zob. Art. 172 Loi $\mathrm{n}^{\circ}$ 2017-86 du 27 janvier 2017 relative à l'égalité et à la citoyenneté, JORF $\mathrm{n}^{\circ} 0024$ du 28 janvier 2017, texte $\mathrm{n}^{\circ} 1$.

68 „Każdy duchowny lub inny szafarz religii, który podczas wykonywania lub przy okazji wykonywania swoich funkcji, publicznie przed tłumem, w kościele lub w innym miejscu przeznaczonym do zgromadzeń religijnych, przed więcej niż jedną osobą, angażuje się w oświadczenia lub dyskusje na temat spraw państwowych, które mogą mieć wpływ na publiczny spokój, podlega karze pozbawienia wolności lub zatrzymania na okres więcej niż dwóch lat. Każdy duchowny lub inny szafarz religii będzie ukarany tą samą karą, jeśli w trakcie wykonywania lub przy okazji wykonywania swoich funkcji wyda lub rozpropaguje pismo zawierające lub dotyczące spraw Państwa, oświadczenia lub dyskusje, które mogą wpłynąć na spokój publiczny". Tekst dostępny w: F. Messner, Code pénal local..., s. 492-493.

${ }^{69}$ Commission des lois constitutionnelles, de la législation et de l'administration générale de la République, Compte rendu n 90, http:/ / www.assemblee-nationale.fr/15/ cr-cloi/17-18/c1718090.asp (dostęp: 10.01.2020 r.). 
Komisja Wenecka zbadała przepisy państw europejskich w zakresie bluźnierstwa, zniewagi religijnej oraz nawoływania do nienawiści religijnej. Efekty jej pracy zostały uzupełnione o wnioski wynikające z międzynarodowej konferencji naukowej Art and Sacred Beliefs: from Collision to Co-existence, która miała miejsce 31 stycznia i 1 lutego 2008 r. w Atenach. Komisja Wenecka w swojej opinii wskazała m.in na konieczność zapewnienia możliwości krytyki poglądów religijnych („It must be possible to criticise religious ideas, even if such criticism may be perceived by some as hurting their religious feelings. Awards of damages should be carefully and strictly justified and motivated and should be proportional, lest they should have a chilling effect on freedom of expression"), a także na konieczność uchylenia przestępstwa bluźnierstwa z systemu prawa karnego (,The offence of blasphemy should be abolished (which is already the case in most European States) and should not be reintroduced"). Na tym tle widać wyraźnie, że uchylenie przestępstwa bluźnierstwa z przepisów lokalnego prawa karnego Alzacji-Mozeli w 2017 r. było zgodne ze standardem europejskim ${ }^{70}$.

\section{Zakończenie}

Przestępstwo bluźnierstwa przeciwko Bogu zostało usunięte z prawa francuskiego w 1791 r. Stosunek państwa do religii na przestrzeni lat spowodował zmianę przedmiotu ochrony z Boga na przekonania religijne. Było to związane $\mathrm{z}$ uznaniem wolności słowa za fundament republikańskiej formy rządów. Dzięki analizie przepisów lokalnego prawa karnego Alzacji-Mozeli oraz przepisów karnych ustawy z dnia 29 lipca 1881 r. o wolności prasy można wyprowadzić wniosek, że osoby wierzące są chronione prawnie przed wszelkimi formami dyskryminacji. Pomimo odrębności lokalnego prawa karnego opartego na reżimie konkordatowym również w prawie lokalnym Alzacji-Mozeli zatryumfowały tendencje ogólnokrajowe, co doprowadziło do uchylenia przestępstwa bluźnierstwa w 2017 r. Przedstawiona w artykule ewolucja od przestępstwa bluźnierstwa do prawnokarnej ochrony przekonań

70 CDL-AD(2008)026, Report on the relationship between freedom of expression and freedom of religion: the issue of regulation and prosecution of blasphemy, religious insult and incitement to religious hatred, § 89; zob. także § 92 . 
religijnych pozwala na stwierdzenie, że ochroną prawną objęte są przekonania religijne. Aktualnie we francuskim prawie karnym, w tym także obowiązującym w trzech departamentach: Górnym Renie, Dolnym Renie, Mozeli, obowiązują przepisy odnoszące się do ochrony przekonań religijnych. Przede wszystkim są to przepisy art. 625-7; 625-8; 625-8-1; 625-8-2 k.k., a także przepisy karne ustawy z dnia 29 lipca 1881 r. o wolności prasy. Również ustawa z 1905 r. gwarantuje każdemu możliwość wyrażania przekonań religijnych w życiu publicznym. W 2017 r. francuski k.k. zaostrzył sankcje karne w stosunku do przestępstwa zniesławienia i zniewagi, jakich można się dopuścić przeciwko osobie lub grupie osób z powodu przynależności religijnej. W konsekwencji zmiana przedmiotu ochrony z Boga na przekonania religijne spowodowała wzmocnienie ochrony prawnej ludzi wierzących przed różnymi formami zachowania dyskryminującymi ich uczucia religijne, w szczególności w miejscach niepublicznych.

\section{Bibliografia}

Draguła A., Bluźnierstwo. Między grzechem a przestępstwem, Warszawa 2013.

Malaurie M., Cours de droit civil, les personnes, les incapacites, Paris 1989.

Massis T., La liberté de conscience, le sentiment religieux et le droit pénal, Chron. XXII, Dalloz 1992.

Messner F., Code pénal local (Alsace-Moselle), w: Droit des religions en France et en Europe: Recueil de textes, red. F. Curtit, F. Messner, Bruxelles 2008.

Okrzesik A., Bluźnierstwo. W prawie świeckim, w: Encyklopedia Katolicka, t. 2, red. F. Gryglewicz, R. Łukaszczyk, Z. Sułowski, Lublin 1995.

Riassetto I., Religion et droit penal en France, in Religion and criminal law, red. M. Kotiranta, N. Doe, Leuven 2013.

Sacquin M., Entre Bossuet et Maurras: l'antiprotestantisme en France de 1814 à 1870, Mémoires et Documents de L'École des Chartes, Paris 1998.

Stachowiak L., Bluźnierstwo, w: Encyklopedia Katolicka, t. 2, red. F. Gryglewicz, R. Łukaszczyk, Z. Sułowski, Lublin 1976.

Wasil W., Od bluźnierstwa do przestępstwa, czyli co tak naprawdę chroni państwo: Boga czy uczucia religijne? Studium historyczno-prawne, Kościół i Prawo 8(21)2019, nr 1. 


\section{Streszczenie}

Najważniejszy akt prawny rewolucji francuskiej nie odnosił się do bluźnierstwa, całkowite zaś usunięcie tego przestępstwa z sytemu francuskiego prawa karnego nastąpiło na mocy przepisów ustawy z 29 lipca 1881 r. o wolności prasy. Szczególną ochroną prawną, na mocy przepisów tej ustawy, została objęta wolność słowa. Przepisy karne ustawy o wolności prasy przewidują ochronę osób wierzących, jak i niewierzących przed wszelkimi formami dyskryminacji, także religijnej. Konstytucyjna zasada świeckości państwa nie uchyliła lokalnego prawa karnego, w tym bluźnierstwa, obowiązującego w trzech departamentach: Górnym Renie, Dolnym Renie, Mozeli do 2017 r. Usunięcie bluźnierstwa z lokalnego prawa karnego to element konsekwentnie wdrażanej aksjologii republikańskiej formy rządów z podporządkowaniem prawa idei państwa świeckiego. Francuski Kodeks karny zaostrzył sankcje karne za popełnienie przestępstw zniesławienia religijnego oraz zniewagi, jakiej można dopuścić się przeciwko osobie lub grupie osób z powodu przynależności religijnej. Aktualnie we francuskim prawie karnym przedmiotem ochrony jest wolność słowa, a także przekonania religijne.

Słowa kluczowe: francuskie prawo karne, bluźnierstwo, lokalne prawo karne Alzacji-Mozeli, świeckość, przekonania religijne

\section{FROM BLASPHEMY TO THE PROTECTION OF RELIGIOUS CONVICTIONS IN FRENCH CRIMINAL LAW}

\section{Summary}

The most important legal act of the French Revolution did not refer to blasphemy. Removal of this crime from the French criminal law system took place under the provisions of the Act of 29 July 1881 on Freedom of the Press. Special legal protection, under the provisions of this Act, has been extended to freedom of speech. Currently, the actions protected under French criminal law is freedom of expression and, on the other hand, freedom from discrimination. Criminal provisions of the Act of 29 July 1881 on freedom of the press provides the protection of believers and non-believers against all forms of discrimination, including religious ones. The constitutional principle of secularism (laïcité) of the state has not exempted local Alsacien-Mosellan criminal law, including the blasphemy which was in force in Alsace-Moselle since 1871 until 2017. The removal of blasphemy from local Alsacien-Mosellan criminal law is part of the consistently implemented axiology of republican values with the subordination of the law to the idea of laïcité. The French Penal Code has strengthened the legal protection of believers 
against various forms of behavior discriminating against their religious feelings, in particular in non-public spaces.

Key words: French criminal law, blasphemy, local criminal law of Alsace-Moselle, laïcité, religious convictions, secularism

\section{ОТ ПРЕСТУПЛЕНИЯ БОГОХУЛЬСТВА ДО УГОЛОВНО-ПРАВОВОЙ ЗАЩИТЫ РЕЛИГИОЗНЫХ УБЕЖДЕНИЙ ВО ФРАНЦУЗСКОМ УГОЛОВНОМ ПРАВЕ}

\section{Резюме}

Самый важный правовой акт Французской революции не относился к богохульству, а полное исключение этого преступления из французской уголовно-правовой системы произошло в соответствии с положениями Закона от 29 июля 1881 г. о свободе печати. В соответствии с положениями этого Закона - свобода слова пользуется особой правовой защитой. Уголовные положения Закона о свободе печати предусматривают защиту верующих и неверующих от всех форм дискриминации, включая религиозную дискриминацию. Конституционный принцип светскости государства не отменял местное уголовное право, включая богохульство действующее в трех департаментах Эльзас-Мозеля до 2017 года. Исключение богохульства из местного уголовного права - элемент последовательно реализуемой аксиологии республиканской формы правления с подчинением закона идее светского характера государства. Уголовный кодекс Франции ужесточил уголовные санкции за совершение преступлений, связанных с клеветой на религиозной почве, и преступлений, которые могут быть совершены против лица или группы лиц на основании религиозной принадлежности. В настоящее время во французском уголовном праве предметом защиты является свобода слова, а также религиозные убеждения.

Ключевые слова: французское уголовное право, богохульство, уголовное право Эльзас-Мозеля, светскость, религиозные убеждения 